\title{
Genomic Comparison of Conjugative Plasmids from Salmonella enterica and Escherichia coli Encoding Beta-Lactamases and Capable of Mobilizing Kanamycin Resistance Col-like Plasmids
}

\author{
Elizabeth A. McMillan ${ }^{1}{ }^{(D)}$, Ly-Huong T. Nguyen $^{2}$, Lari M. Hiott ${ }^{1}$, Poonam Sharma ${ }^{3}$ (D) Charlene R. Jackson ${ }^{1}(\mathbb{D}$, \\ Jonathan G. Frye ${ }^{1, * \mathbb{D}}$ and Chin-Yi Chen ${ }^{2}$ (D)
}

1 U.S. Department of Agriculture, Agricultural Research Service, U.S. National Poultry Research Center, Bacterial Epidemiology and Antimicrobial Resistance Research Unit, Athens, GA 30605, USA; elizabeth.mcmillan@usda.gov (E.A.M.); lari.hiott@usda.gov (L.M.H.); charlene.jackson@usda.gov (C.R.J.)

2 U.S. Department of Agriculture, Agricultural Research Service, Eastern Regional Research Center, Molecular Characterization of Foodborne Pathogens Research Unit, Wyndmoor, PA 19038, USA; ly.nguyen@usda.gov (L.-H.T.N.); chin-yi.chen@usda.gov (C.-Y.C.)

3 Institute of Biosecurity and Microbial Forensics, Department of Biochemistry and Molecular Biology, Oklahoma State University, Stillwater, OK 74078, USA; poonam.sharma@okstate.edu

check for updates

Citation: McMillan, E.A.; Nguyen, L.-H.T.; Hiott, L.M.; Sharma, P.; Jackson, C.R.; Frye, J.G.; Chen, C.-Y. Genomic Comparison of Conjugative Plasmids from Salmonella enterica and Escherichia coli Encoding

Beta-Lactamases and Capable of Mobilizing Kanamycin Resistance Col-like Plasmids. Microorganisms 2021, 9, 2205. https://doi.org/ 10.3390/microorganisms 9112205

Academic Editors: Carlo Pazzani and Maria Scrascia

Received: 29 September 2021

Accepted: 21 October 2021

Published: 23 October 2021

Publisher's Note: MDPI stays neutral with regard to jurisdictional claims in published maps and institutional affiliations.

Copyright: (c) 2021 by the authors. Licensee MDPI, Basel, Switzerland. This article is an open access article distributed under the terms and conditions of the Creative Commons Attribution (CC BY) license (https:// creativecommons.org/licenses/by/ $4.0 /)$.
* Correspondence: jonathan.frye@usda.gov

Abstract: Salmonella enterica and Escherichia coli are important human pathogens that frequently contain plasmids, both large and small, carrying antibiotic resistance genes. Large conjugative plasmids are known to mobilize small Col plasmids, but less is known about the specificity of mobilization. In the current study, six S. enterica and four E. coli strains containing large plasmids were tested for their ability to mobilize three different kanamycin resistance Col plasmids (KanR plasmids). Large conjugative plasmids from five isolates, four S. enterica and one E. coli, were able to mobilize KanR plasmids of various types. Plasmids capable of mobilizing the KanR plasmids were either IncI1 or IncX, while IncI1 and IncX plasmids with no evidence of conjugation had disrupted transfer regions. Conjugative plasmids of similar types mobilized similar KanR plasmids, but not all conjugative plasmid types were capable of mobilizing all of the KanR plasmids. These data describe some of the complexities and specificities of individual small plasmid mobilization.

Keywords: plasmids; conjugation; Salmonella; E. coli

\section{Introduction}

Both Salmonella enterica and Escherichia coli are common causes of foodborne illness in the United States and globally [1]. Combined, Salmonella and Shiga-toxin producing E. coli were responsible for $23.4 \%$ of reported foodborne illnesses in 2019 at sites participating in FoodNet in the U.S. [2]. Unfortunately, an increasing number of these infections display resistance to antibiotics [3]. Many of the genes conferring these resistances are carried by plasmids, both large and small, which could increase the mobility of these genes and by extension increase the spread of antibiotic resistance [4]. For example, $\beta$-lactamase genes, bla $a_{\mathrm{CMY}-2}$ in particular, have been shown to frequently be carried by large plasmids especially of types IncA/C and IncI1 in Salmonella [5].

While many large plasmids are able to transfer to new cells independently via conjugation, not all plasmids are self-transmissible. Mobilizable plasmids are those that cannot transfer via conjugation on their own, but require a "helper plasmid" possessing the necessary genes to encode the mate-pair structures which mobilizable plasmids can utilize to transfer to a new cell [6]. Mobilizable plasmids may utilize their own relaxase/nikase or those present on the conjugative helper plasmid [7,8]. Many large plasmids, such as types IncF, IncP, and IncI1, have proven capable of mobilizing small plasmids [9]. However, 
less attention has been given to the differences in mobilization capabilities of these large conjugative plasmids.

Previously, small ColE-like plasmids carrying kanamycin resistance $a p h\left(3^{\prime}\right)$-I genes were categorized based on their plasmid replication/maintenance region and mobilization gene(s) [10-14]. In order to investigate the specifics of mobilization of these KanR plasmids, we screened a collection of $\beta$-lactam resistant Salmonella and E. coli strains for large plasmids and the ability of those large plasmids to mobilize varying KanR plasmids in tri-parental mating experiments. For isolates producing transconjugants, whole genome sequencing and further comparison of the plasmid sequences were completed.

\section{Materials and Methods}

\subsection{Strains}

To maximize potential for presence of large plasmids, $\beta$-lactam-resistant, KAN STRsusceptible Salmonella enterica $(n=6)$ and Escherichia coli $(n=4)$ isolates were selected from a collection of multidrug resistant isolates of animal origin (Table 1). Isolates were tested for their ability to convert E. coli NEB10 $\beta$ to AMP-resistant via conjugation overnight. The plasmid replicon types and the $\beta$-lactamases present in the original isolates and their transconjugants were characterized using a PCR-based plasmid replicon typing kit (PBRT; Diatheva, Cartoceto, Italy) and the ARM-D $\beta$-lactamases ID kit (Streck, La Vista, NE, USA), respectively. The transconjugants were screened for the absence of small plasmids by extracting DNA using QIAprep Spin Miniprep kit (Qiagen, Germantown, MD, USA), and clones without visible small plasmids were chosen for further testing (described below) for their ability to mobilize different ColE-like kanamycin resistance plasmids (KanR plasmids) $[10,12,13]$. Of those, three isolates were selected for sequencing $(n=2$ S. enterica, $n=1 \mathrm{E}$. coli) and one isolate, strain five (CRJJGF_00030), was sequenced and characterized as a part of a previous study [15]. A transformant containing the I1 plasmid of isolate \#2 and the transconjugants of isolates \#3, \#5, and \#12 were also sequenced.

\subsection{KanR Plasmid Mobilization Tests on Agar}

The ability of the conjugative plasmids to mobilize different KanR plasmids (pU302S [10], pSN11/00Kan [12], and pSe-Kan [13]) was tested using tri-parental mating on agar for qualitative assessment. Cultures of donor (NEB5 $\alpha$ carrying KanR plasmid; KAN ${ }^{\mathrm{R}}$ ), recipient CAG18483 (TET ; F-, fadL771:Tn10, obtained from Coli Genetic Stock Center, \#7407), and helper (NEB10 $\beta$ carrying conjugative plasmid; $\mathrm{AMP}^{\mathrm{R}}$ ) were adjusted to $\sim 10^{8} \mathrm{CFU} / \mathrm{mL}$ and mixed at the ratio of 1:5:1 (10 $\mu \mathrm{L}: 50 \mu \mathrm{L}: 10 \mu \mathrm{L})$ on a LB agar plate, and incubated at $37^{\circ} \mathrm{C}$ for six hours. Mating mixtures were then resuspended into LB broth and plated on LB agar supplemented with kanamycin A $(50 \mathrm{mg} / \mathrm{L})$ and tetracycline- $\mathrm{HCl}(2 \mathrm{mg} / \mathrm{L})$ for selection. Plates were incubated overnight at $37^{\circ} \mathrm{C}$ and the KanR plasmid mobilization was scored as positive or negative. 
Table 1. Strain characterization: antibiogram, plasmid replicon typing, and $\beta$-lactamase gene.

\begin{tabular}{|c|c|c|c|c|c|c|c|c|c|c|}
\hline \multicolumn{7}{|c|}{ Original Isolate } & \multicolumn{4}{|c|}{ Neb10 $\beta$ Transconjugant } \\
\hline Strain & Organism & $\begin{array}{l}\text { Isolation } \\
\text { Source }\end{array}$ & $\begin{array}{l}\text { Resistance } \\
\text { Profile }^{\mathrm{a}}\end{array}$ & $\begin{array}{c}\text { Replicon Type } \\
\text { (PBRT) }^{\mathbf{b}} \\
\text { [Sequencing] }\end{array}$ & bla Gene ${ }^{\mathrm{c}}$ & $\mathrm{NGS}^{\mathrm{d}}$ & Clone ID ${ }^{\mathrm{e}}$ & $\begin{array}{l}\text { Replicon Type } \\
\text { (PBRT) } \\
\text { [Sequencing] }\end{array}$ & $\begin{array}{c}\text { bla Gene }{ }^{c} \\
\text { [Sequencing] }\end{array}$ & $\begin{array}{l}\text { KanR Plasmid } \\
\text { Mobilization } f\end{array}$ \\
\hline 1 & $\begin{array}{l}\text { S. enterica } \\
\text { Infantis }\end{array}$ & Cattle & $\begin{array}{l}\text { AMP AUG AXO } \\
\text { CEP FOX TIO }\end{array}$ & I1 & CMY-2 & & TC1d & I1 & CMY-2 & N.D. \\
\hline 2 & $\begin{array}{l}\text { S. enterica } \\
\text { Heidelberg }\end{array}$ & Cattle & $\begin{array}{l}\text { AMP AUG AXO } \\
\text { CEP FOX TIO }\end{array}$ & $\begin{array}{c}\mathrm{I} 1, \mathrm{X} 1 \\
{[\mathrm{ColVC}]}\end{array}$ & CMY-2 & $\sqrt{ }$ & $\mathrm{LCp} 2$ * & $\begin{array}{c}\mathrm{I} 1 \\
{[\mathrm{ColVC}]}\end{array}$ & CMY-2 & All \\
\hline 3 & $\begin{array}{c}\text { S. enterica } \\
\text { Typhimurium } \\
\text { var. 5- }\end{array}$ & Cattle & $\begin{array}{l}\text { AMP AUG AXO } \\
\text { CEP FOX TIO }\end{array}$ & $\begin{array}{c}\mathrm{I} 1, \mathrm{FIB}, \mathrm{X} 1 \\
{[\mathrm{FIC}, \mathrm{ColVC}]}\end{array}$ & CMY-2 & $\sqrt{ }$ & $\mathrm{TC} 3 \mathrm{c}$ & $\mathrm{X} 1$ & Unk [TEM-1] & pSN11/00Kan \\
\hline 4 & $\begin{array}{c}\text { S. enterica } \\
\text { Typhimurium }\end{array}$ & Cattle & $\begin{array}{l}\text { AMP AUG AXO } \\
\text { CEP FOX TIO }\end{array}$ & I1, FIIS & CMY-2 & & TC4d & I1 & CMY-2 & All \\
\hline 5 & $\begin{array}{l}\text { S. enterica } \\
\text { Infantis }\end{array}$ & Chicken & $\begin{array}{l}\text { AMP AUG AXO } \\
\text { FOX TIO }\end{array}$ & $\mathrm{I} 1$ & CMY-2 & $\sqrt{ }$ & TC5f & $\begin{array}{c}\mathrm{I} 1 \\
{[\mathrm{ColVC}]}\end{array}$ & CMY-2 & All \\
\hline 6 & $\begin{array}{l}\text { S. enterica } \\
\text { Saintpaul }\end{array}$ & Turkey & $\begin{array}{l}\text { AMP AUG AXO } \\
\text { FOX TIO }\end{array}$ & $\mathrm{I} 1, \mathrm{X} 1$ & CMY-2 & & TC6d & $\mathrm{I} 1, \mathrm{X} 1$ & CMY-2 & N.D. \\
\hline 7 & E. coli & Chicken & $\begin{array}{l}\text { AMP AUG AXO } \\
\text { COT FIS FOX } \\
\text { GEN NAL TIO }\end{array}$ & I1, FIB, I2, K & CMY-2 & & N.A. & & & \\
\hline 8 & E. coli & Chicken & $\begin{array}{l}\text { AMP AUG AXO } \\
\text { FOX GEN TIO }\end{array}$ & FIB, B/O, K & CMY-2 & & N.A. & & & \\
\hline 10 & E. coli & Chicken & $\begin{array}{c}\text { AMP AUG AXO } \\
\text { FIS FOX GEN TIO }\end{array}$ & $\begin{array}{c}\mathrm{I} 1, \mathrm{FIB}, \mathrm{X} 1, \mathrm{~B} / \mathrm{O} \\
\mathrm{K}\end{array}$ & CMY-2 & & N.A. & & & \\
\hline 12 & E. coli & Dog & $\begin{array}{l}\text { AMP AUG AXO } \\
\text { CIP FOX GEN } \\
\text { NAL TIO }\end{array}$ & $\begin{array}{c}\text { I1 [X4, FIA, FIB, } \\
\text { FII, Col] }\end{array}$ & CMY-2 & $\sqrt{ }$ & TC12d & Unk [X4] & CMY-2 & pSN11/00Kan \\
\hline $\begin{array}{l}\text { a Abbr } \\
\text { (FOX), } \\
\text { positi } \\
\text { the pr } \\
\text { availa } \\
\text { plasm }\end{array}$ & $\begin{array}{l}\text { ations: Ampicillir } \\
\text { Ifisoxazole (FIS), } \\
\text { ith any of the pri } \\
\text { rs; sequence resu } \\
{ }^{*} \text {, all transconjug } \\
\text { and. }{ }^{f} \text { via tri-pare }\end{array}$ & $\begin{array}{l}\text { IP), Amoxici } \\
\text { micin (GEN) } \\
\text { additional } \mathrm{r} \\
\text { wn between } \\
\text { howed the } \mathrm{p} \\
\text { mating; N.D }\end{array}$ & $\begin{array}{l}\text { clavulanic acid (AUG) } \\
\text { lidixic acid (NAL), Cef } \\
\text { cons identified using s } \\
\text { tare brackets. }{ }^{d} \text { Strains } \\
\text { nce of } 1 \text { or } 2 \text { small pla } \\
\text { t determined; All, pU3 }\end{array}$ & $\begin{array}{l}\text { Leftriaxone (AXO), C } \\
\text { fur (TIO), Streptomy } \\
\text { uence result shown } \\
\text { transconjugant clone } \\
\text { hid(s); LCp2 was gen } \\
\text { 2S, pSN11/00Kan, an }\end{array}$ & $\begin{array}{l}\text { alothin (CEP), } \\
\text { (STR), Unkno } \\
\text { een square br } \\
\text { the correspo } \\
\text { ed from trans } \\
\text { Se-Kan. }\end{array}$ & $\begin{array}{l}\text { ramphe } \\
\text { nk). }{ }^{b} \mathrm{D} \\
\text { s. }{ }^{\mathrm{c}} \text { Iden } \\
\text { origina } \\
\text { tion of } \mathrm{t}\end{array}$ & $\begin{array}{l}\text { CHL), Ciprof } \\
\text { ined using PC } \\
\text { using ARM-D } \\
\text { te) selected } \mathrm{f} \\
\text { ge-construct }\end{array}$ & $\begin{array}{l}\text { n (CIP), Sulfametho } \\
\text { ed Plasmid Replico } \\
\text { tamase ID kit (Strec } \\
\text { uencing are indicat } \\
\text { id prep (Qiagen) an }\end{array}$ & $\begin{array}{l}\text { zole-trimethoprim } \\
\text { yping kit (Diathev } \\
\text { Unknown, not po } \\
\text { by " } \sqrt{ } \text { ". e N.A., tr } \\
\text { creened for the la }\end{array}$ & $\begin{array}{l}\text { OT), Cefoxitin } \\
\text { Unknown, not } \\
\text { ive with any of } \\
\text { sconjugant not } \\
\text { of visible small }\end{array}$ \\
\hline
\end{tabular}




\subsection{Sequencing}

Strains were sequenced using Nextera XT library kits on an Illumina MiSeq. Raw reads were assembled with A5 [16]. Plasmid replicons were identified using PlasmidFinder (https: / / cge.cbs.dtu.dk/services/PlasmidFinder/; accessed on 31 August 2020) and plasmid contigs were identified using BLAST in comparison to known plasmid sequences in the non-redundant database [17]. Plasmid sequences were annotated using RAST and gene assignments were confirmed using BLAST in comparison to the non-redundant protein database [18]. Antibiotic resistance genes were identified using ResFinder (https:/ / cge.cbs. dtu.dk/services/ResFinder/; accessed on 31 August 2020) [19]. The oriT sequences were identified with oriTFinder [20]. For plasmids where oriTFinder could not identify an oriT sequence, the ori $\mathrm{T}$ was manually annotated based on the homology with the oriT of IncX1 plasmid pOLA52 (NC_010378.1) [21]. Plasmid maps were generated using SnapGene (https: / / www.snapgene.com/; version 4.0.8). The transfer regions of each plasmid were extracted and aligned with the transfer regions of plasmids of similar type within this study as well as the prototypical plasmid of their incompatibility group using Mauve [22]. Prototypical plasmids used were IncX2 plasmid R6K (http:/ / www.sanger.ac.uk/Projects/Plasmids/; accessed on 31 September 2020) and IncI1 plasmid R64 (AP005147.1) [23]. The transfer region for p3I1 could not be aligned because the sequence was discontinuous. Plasmids were compared with the matching transconjugant plasmid using BLAST. The Blast Ring Image Generator (BRIG) was used to generate ring comparison figures [24].

\section{Results}

A total of 10 isolates were investigated, each of which contained at least one large plasmid. All 10 strains also contained a detectable $\beta$-lactamase gene, bla ${ }_{\mathrm{CMY}-2}$. Seven of these strains yielded transconjugants in the bi-parental mating: all S. enterica strains investigated, but only one E. coli strain. Only plasmids of replicon types I1, X1, and $\mathrm{X} 4$ showed evidence of conjugation. However, not all plasmids of these types yielded transconjugants. With the exception of one isolate (strain \#3), bla $a_{\mathrm{CMY}-2}$ was the $\beta$-lactamase gene transferred to the recipient cell (Table 1).

Seven strains were subjected to whole genome sequencing with an average of 252 contigs per sequence. Plasmid replicon genes and antibiotic resistance genes were identified in every sequence (Table 1). Plasmids identified in original strains were named for the isolate number and replicon type. Plasmids in transconjugants were given the same name with a TC designation (Table 2). In each isolate/transconjugant pair, only one large plasmid containing a $\beta$-lactamase gene transferred. However, three of four isolates contained an additional large plasmid that did not transfer (Table 1). Plasmids of IncI1 or IncX type were assembled regardless of whether they transferred or not (Table 2, Supplementary Figures S1 and S2). The transfer regions of both IncI1 plasmids that did not transfer were disrupted by transposons or other sequences (Supplementary Figures S1 and S2). Isolates $\# 2$, \#3, and LCp2 contained a ColVC plasmid approximately $2 \mathrm{~kb}$ in size; the ColVC is partial ( one kb) in TC5f (Table 1).

Plasmids from original isolates were compared to plasmids in transconjugant clones. Plasmids p3X1 and p3X1-TC contained identical sequence with no SNP differences. A $163 \mathrm{bp}$ insertion in a non-coding region of $\mathrm{p} 3 \mathrm{X} 1-\mathrm{TC}$ was determined to be an assembly artifact rather than sequence change; this sequence was also present in the whole genome sequence of the original isolate, but on a small contig that could not be joined to the plasmid. p5I1 and p5I1-TC were identical. p12X4-TC contained all the sequence within p12X4 but had two insertions not contained within the genomic sequence of the original isolate: a $112 \mathrm{bp}$ insertion in a non-coding region and a $275 \mathrm{bp}$ insertion overlapping a non-coding region and transposase gene. p2I1 and the retransformed p2I1-LC contained the same sequence, except for a $258 \mathrm{bp}$ deletion between two genes in the transfer region of p2I1-LC and a $289 \mathrm{bp}$ deletion between two genes outside of the transfer region. However, there were also minor rearrangements related to assembly artifacts and less than 10 mismatches. 
Table 2. Sequenced plasmids information.

\begin{tabular}{ccccc}
\hline Plasmid & Replicon Type & Size $^{\mathbf{a}}$ & AR Genes & Conjugated? \\
\hline p2I1 & $\mathrm{I} 1$ & $100 \mathrm{~kb}$ & $b l a_{\mathrm{CMY}-2}$ & Yes \\
p2I1-LC & $\mathrm{I} 1$ & $100 \mathrm{~kb}$ & $b l a_{\mathrm{CMY}-2}$ & Yes \\
p2X1 & $\mathrm{X} 1$ & $38 \mathrm{~kb}$ & N/A & No \\
p3X1 & $\mathrm{X} 1$ & $43 \mathrm{~kb}$ & $b l a_{\mathrm{TEM}-1}$ & Yes \\
p3X1-TC & $\mathrm{X} 1$ & $43 \mathrm{~kb}$ & $b l a_{\mathrm{TEM}-1}$ & Yes (Transconjugant) \\
p3I1 & $\mathrm{I} 1$ & $101 \mathrm{~kb}$ & $b l a_{\mathrm{CMY}-2}$ & No \\
p5I1 & $\mathrm{I} 1$ & $99 \mathrm{~kb}$ & $b l a_{\mathrm{CMY}-2}$ & Yes \\
p5I1-TC & $\mathrm{I} 1$ & $99 \mathrm{~kb}$ & $b l a_{\mathrm{CMY}-2}$ & Yes (Transconjugant) \\
p12X4 & $\mathrm{X} 4$ & $37 \mathrm{~kb}$ & $b l a_{\mathrm{CMY}-2}$ & Yes \\
p12X4-TC & $\mathrm{X} 4$ & $37 \mathrm{~kb}$ & $b l a_{\mathrm{CMY}-2}$ & Yes (Transconjugant) \\
p12I1 & $\mathrm{I} 1$ & $94 \mathrm{~kb}$ & N/A & No \\
\hline
\end{tabular}

a Size is approximate to the nearest whole number. ${ }^{\mathrm{b}} \mathrm{LC}=$ large construct. ${ }^{\mathrm{c}}$ Transformant was used for the sequencing and characterization.

Alignments were generated comparing the transfer region of each plasmid of similar Inc type to each other and to a prototypical plasmid of each type. Plasmids were also compared to the plasmid of similar type that did not transfer (Figures 1 and 2; Supplementary Figures S3 and S4). IncX1 plasmids showed more similarity to each other than to the IncX4 plasmid or the prototypical IncX plasmid, which is IncX2 (Figure 1; Supplementary Figure S3). IncI1 plasmids showed homology in their transfer regions, except p12I1, which contained both an insertion and deletion (Figure 2; Supplementary Figure S4).
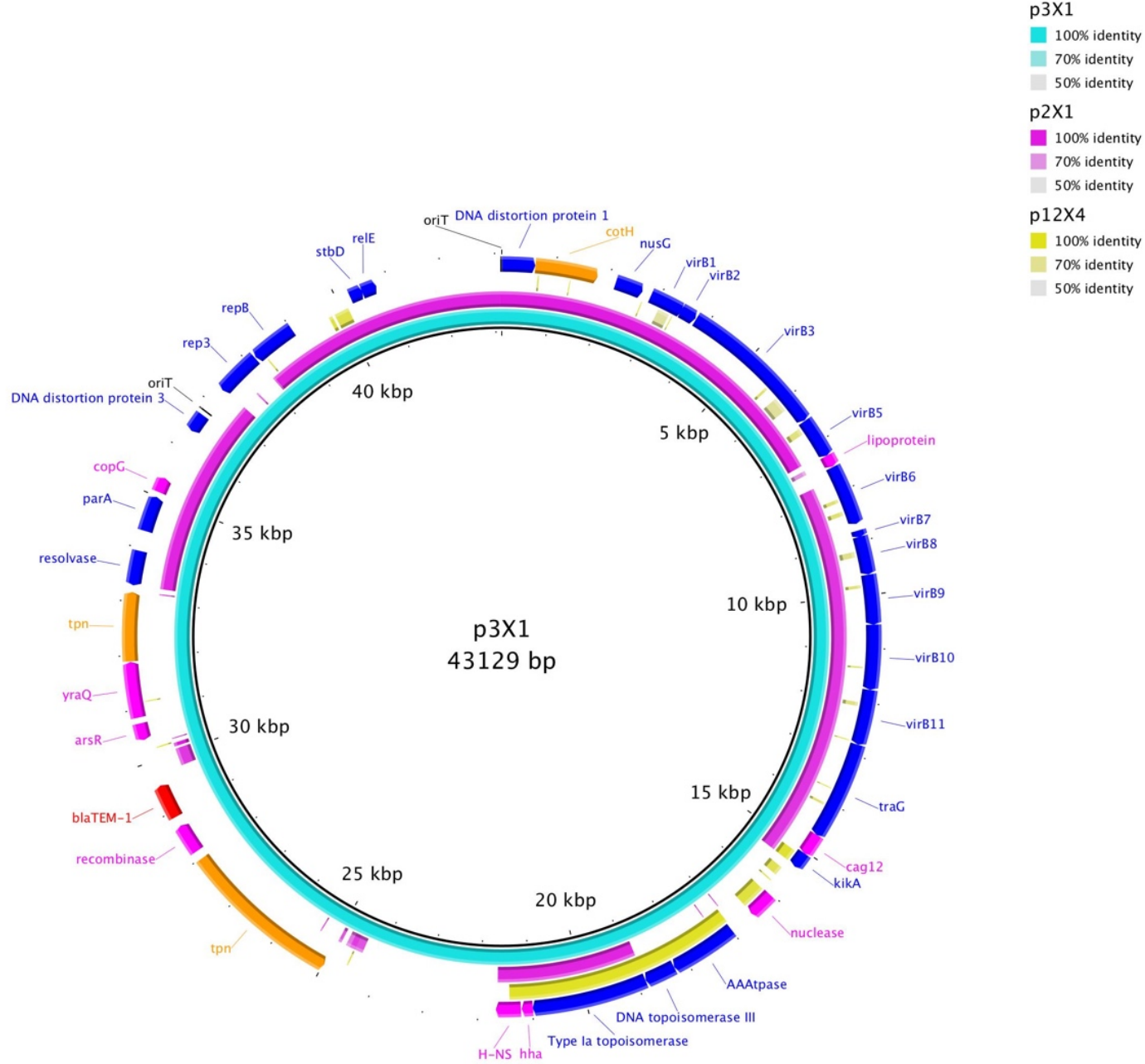

Figure 1. Blast comparison of the IncX plasmids. 


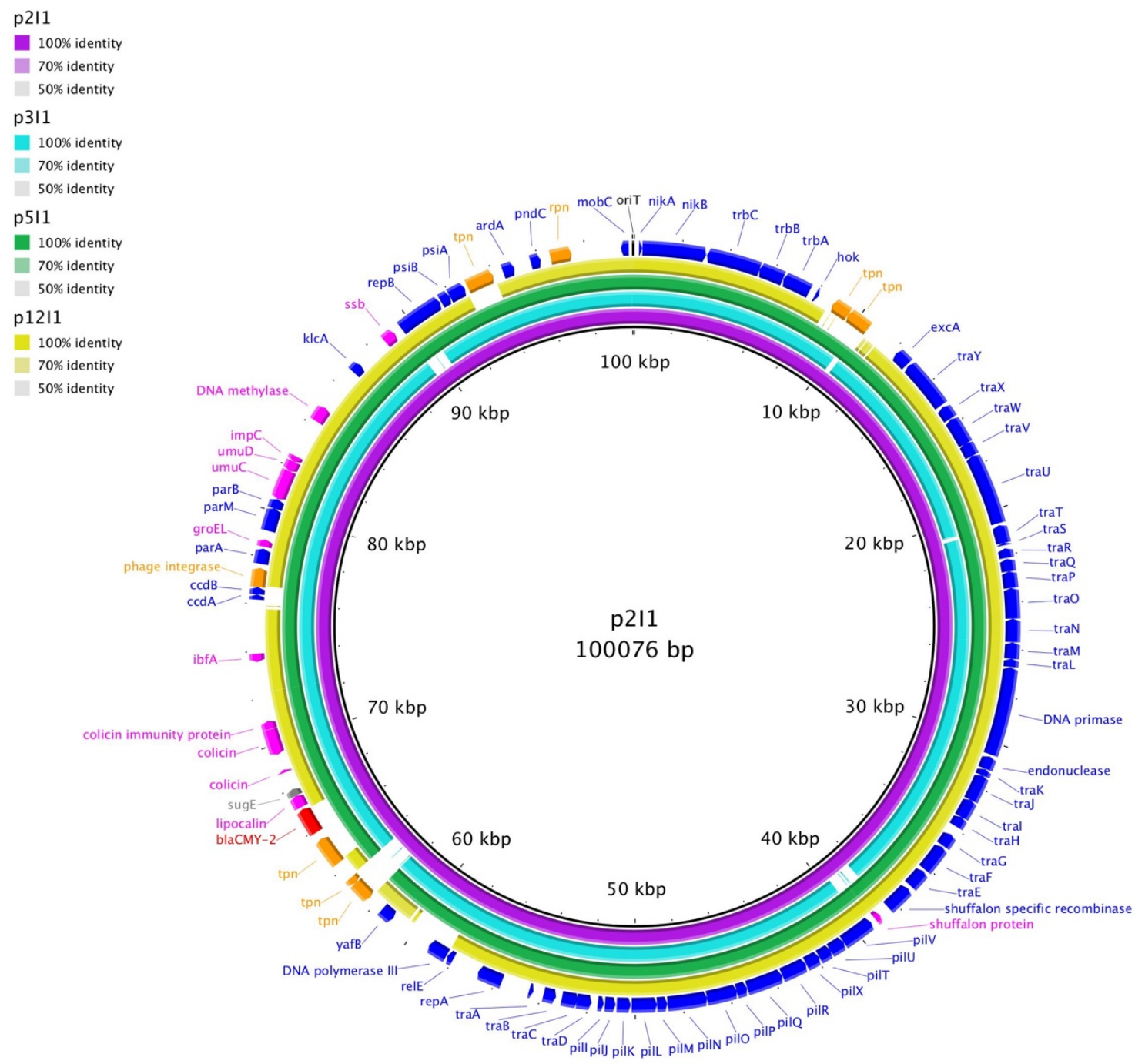

Figure 2. Blast comparison of IncI1 plasmids.

Conjugative plasmids from at least five of the 10 original isolates were capable of mobilizing small plasmids (Table 3), four of which were sequenced: p2I1, p3X1, p5I1, and p12X4 (and those in the corresponding transconjugant/transformant p2I1-LC, p3X1TC, p5I1-TC, and p12X4-TC). These plasmids were able to mobilize the KanR plasmids investigated with varying success. Plasmids of the same Inc type were able to mobilize the same small plasmids. pSN11/00Kan, which carries the mobC-mobABD operon, can be mobilized by all conjugative plasmids tested (IncI1, X1, and X4). Neither IncX plasmid could mobilize plasmids pU302S (carries nikA) or pSe-Kan (does not carry known mob genes), which suggests the Col plasmid-borne mob genes are required for IncX assisted plasmid mobilization (Table 3).

Table 3. Qualitative assessment of KanR plasmid mobilization using tri-parental agar mating. + indicates donor plasmid was mobilized, - indicates donor plasmid was not mobilized.

\begin{tabular}{ccccccc}
\hline \multirow{2}{*}{ Donor Plasmid } & Mobilization Genes & \multicolumn{5}{c}{ Helper Strain } \\
\cline { 3 - 7 } & & LCp2 & TC3c & TC4d & TC5f & TC12d \\
\hline pU302S & nikA & + & - & + & + & - \\
pSN11/00Kan & mobC-mobABD & + & + & + & + & + \\
pSe-Kan & Unknown & + & - & + & + & - \\
\hline
\end{tabular}




\section{Discussion}

Plasmids and $\beta$-lactamase genes were identified in 10 isolates $(n=6$ S. enterica and $n=4 E$. coli). We then determined the ability of the large plasmids in each isolate to mobilize small KanR plasmids. In all but one case, only one large plasmid transferred via conjugation (selected for AMP resistance) in each isolate regardless of the number of large plasmids present in each isolate. KanR plasmids were mobilized with varying success, depending on plasmid type.

Here we showed that $\mathrm{pU} 302 \mathrm{~S}$, which carried just oriT and a nikA accessory protein, can be mobilized by IncI1 (p2I1-LC and p5I1-TC). This provided the only other experimental evidence than that of NTP16 that this group of diverse plasmids which lacks a relaxase may be mobilized by the IncI family [25]. While mobilization of plasmids lacking a relaxase has been documented, the essential genes necessary for transfer, which are provided by a conjugative plasmid, have not been specified yet. IncI1 plasmids also mobilized pSN11/00Kan, the KanR plasmid carrying the mobC-mobABD mobilization region, as well as the pSe-Kan which possesses two different oriT regions but no other identifiable mobilization accessory protein.

Plasmids from original isolates were nearly identical to their transconjugants. While there were minor differences in the sequences of these plasmids, it is most likely that these differences are related to sequencing and/or assembly error, rather than genetic change. Sequencing and assembly can introduce errors into the final sequence, especially in repetitive elements [26]. Further, the insertions and deletions detected were present near the beginning and ends of contigs and less than the average length of a paired end read. Long-read sequences combined with the short reads collected here would help resolve these discrepancies.

Both IncI1 plasmids that did not transfer had disrupted transfer regions. In p12I1, the transfer region was disrupted by a partial bla ${ }_{\mathrm{CMY}-2}$ gene, the insertion occurring where tra $\mathrm{G}$ is located in the other IncI1 plasmids investigated. In p3I1, the transfer region was disrupted in several places by transposons: inserted between the traT and traU genes, between traM and traN, and inside the DNA primase. It was not possible to close the assembly of p3I1 because there was no overlap of contig ends, possibly because of insertion of these transposons and repetitive elements, which can be difficult to sequence. In contrast, the IncX1 plasmid that did not transfer ( $\mathrm{p} 2 \mathrm{X} 1$ ) had complete transfer regions similar to p3X1, which was conjugative. It is possible that this plasmid is conjugative but either did not transfer, or transconjugants containing this plasmid were not selected because the plasmid did not contain a $\beta$-lactamase gene.

Isolates \#2 and \#3 contained a 2-kb ColVC plasmid. The ColVC plasmids in the two isolates were identical and appeared to be transferrable. All the transconjugants derived from isolate \#2 carried additional small plasmid(s), as well as the sequenced transformant, LCp2. While the isolate \#5 sequence did not contain a ColVC plasmid, transconjugant clone TC5f did. Isolate \#5 was sequenced as part of another study using a different sequencing technology several years prior to this investigation. It is possible that the plasmid was not detected because the conjugation experiments were not conducted with the same culture (different retrieval from frozen storage) or that the sequencing technology did not detect the plasmid at the time of sequencing. Considering that only those transconjugant clones without visible small plasmid bands were selected for further investigation, it was unexpected to find that some TC clones still possessed ColVC plasmids within their whole genome sequence. Possible explanations for this discrepancy between sequencing and wet lab results could be (1) the ColVC plasmid may be present in lower copy number than other small plasmids, resulting in more varied miniprep yield between different samples that sometimes failed to be visualized on the gel; (2) uncut, supercoiled plasmids tend to run as smears, not sharp bands, on agarose gel, and do not take up DNA intercalating dyes easily, thus further reducing detection sensitivity. None of the ColVC plasmids contained any antibiotic resistance genes but their presence and the ability to be co-transferred does highlight the relevance of Col plasmids in natural environments. 
In conclusion, similar types of large conjugative plasmids were able to mobilize the same (sub)group of KanR plasmids. Plasmids with disrupted transfer regions were not able to conjugate. We were able to show that the nikA-carrying KanR plasmid can be mobilized by IncI1 plasmids but not the IncX plasmids. Further studies with additional replicon types are needed to understand the full range of large plasmids capable of mobilizing these and other Col plasmids and will be important in understanding the transfer risk of a given antibiotic resistance gene.

Supplementary Materials: The following are available online at https:/ /www.mdpi.com/article/10 .3390/microorganisms9112205/s1, Figure S1: IncI1 plasmids investigated, Figure S2: IncX plasmids investigated, Figure S3: progressiveMauve alignment of the transfer regions of R6K, p2X1, p3X1-TC, and p12X4-TC, Figure S4: progressiveMauve alignment of the transfer regions of R64, p2I1, p5I1-TC, and $\mathrm{p} 12 \mathrm{II}$.

Author Contributions: Conceptualization, E.A.M., C.-Y.C. and J.G.F.; methodology, E.A.M., L.H.T.N., L.M.H., P.S. and C.-Y.C.; validation, E.A.M., L.-H.T.N., L.M.H., P.S. and C.-Y.C.; formal analysis, E.A.M., L.-H.T.N., L.M.H. and P.S.; investigation, E.A.M., L.-H.T.N., L.M.H., P.S. and C.-Y.C.; resources, C.R.J., J.G.F. and C.-Y.C.; data curation, E.A.M. and P.S.; writing—original draft preparation, E.A.M. and C.-Y.C.; writing-review and editing, all authors; visualization, E.A.M.; supervision, C.R.J., J.G.F. and C.-Y.C.; project administration, C.R.J., J.G.F. and C.-Y.C.; funding acquisition, C.R.J., J.G.F. and C.-Y.C. All authors have read and agreed to the published version of the manuscript.

Funding: This work was supported by the U.S. Department of Agriculture, Agricultural Research Service internal project plans 8072-42000-091-000-D and 6040-32000-079-000-D. E.A.M. was supported by a USDA ARS Headquarters Postdoctoral Fellowship.

Institutional Review Board Statement: Not applicable.

Informed Consent Statement: Not applicable.

Data Availability Statement: Sequences generated as a result of this study can be accessed via NCBI under BioProject number PRJNA756294.

Acknowledgments: Authors would like to acknowledge Asseta Kagambega for technical assistance during isolate sequencing.

Conflicts of Interest: The authors declare no conflict of interest. The funders had no role in the design of the study; in the collection, analyses, or interpretation of data; in the writing of the manuscript, or in the decision to publish the results.

Disclaimer: The findings and conclusions in this report are those of the author(s) and should not be construed to represent any official USDA or U.S. Government determination or policy. Mention of trade names or commercial products in this publication is solely for the purpose of providing specific information and does not imply recommendation or endorsement by the U.S. Department of Agriculture. USDA is an equal opportunity provider and employer.

\section{References}

1. Scallan, E.; Hoekstra, R.M.; Angulo, F.J.; Tauxe, R.V.; Widdowson, M.A.; Roy, S.L.; Jones, J.L.; Griffin, P.M. Foodborne illness acquired in the United States-Major pathogens. Emerg. Infect. Dis. 2011, 17, 7-15. [CrossRef]

2. Tack, D.M.; Ray, L.; Griffin, P.M.; Cieslak, P.R.; Dunn, J.; Rissman, T.; Jervis, R.; Lathrop, S.; Muse, A.; Duwell, M.; et al. Preliminary incidence and trends of infections with pathogenes transmitted commonly through food-Foodborne diseases active surveillance network, 10 U.S. sites, 2016-2019. Morb. Mortal. Wkly. Rep. 2020, 69, 509-514. [CrossRef] [PubMed]

3. CDC. Antibiotic Resistance Threats in the United States; CDC: Atlanta, GA, USA, 2019.

4. Carattoli, A. Plasmids and the spread of resistance. Int. J. Med. Microbiol. 2013, 303, 298-304. [CrossRef]

5. Folster, J.P.; Pecic, G.; McCullough, A.; Rickert, R.; Whichard, J.M. Characterization of bla(CMY)-encoding plasmids among Salmonella isolated in the United States in 2007. Foodborne Pathog. Dis. 2011, 8, 1289-1294. [CrossRef] [PubMed]

6. Loftie-Eaton, W.; Rawlings, D.E. Diversity, biology and evolution of IncQ-family plasmids. Plasmid 2012, 67, 15-34. [CrossRef] [PubMed]

7. Zechner, E.L.; Moncalián, G.; de la Cruz, F. Relaxases and Plasmid Transfer in Gram-Negative Bacteria. In Type IV Secretion in Gram-Negative and Gram-Positive Bacteria; Backert, S., Grohmann, E., Eds.; Springer International Publishing: Cham, Switzerland, 2017; pp. 93-113. [CrossRef] 
8. Francia, M.V.; Varsaki, A.; Garcillan-Barcia, M.P.; Latorre, A.; Drainas, C.; de la Cruz, F. A classification scheme for mobilization regions of bacterial plasmids. FEMS Microbiol. Rev. 2004, 28, 79-100. [CrossRef] [PubMed]

9. Warren, G.J.; Saul, M.W.; Sherratt, D.J. ColE1 plasmid mobility: Essential and conditional functions. Mol. Gen. Genet. 1979, 170, 103-107. [CrossRef] [PubMed]

10. Chen, C.Y.; Nace, G.W.; Solow, B.; Fratamico, P. Complete nucleotide sequences of 84.5- and 3.2-kb plasmids in the multi-antibiotic resistant Salmonella enterica serovar Typhimurium U302 strain G8430. Plasmid 2007, 57, 29-43. [CrossRef]

11. Chen, C.Y.; Lindsey, R.L.; Strobaugh, T.P., Jr.; Frye, J.G.; Meinersmann, R.J. Prevalence of ColE1-like plasmids and kanamycin resistance genes in Salmonella enterica serovars. Appl. Environ. Microbiol. 2010, 76, 6707-6714. [CrossRef]

12. Chen, C.Y.; Strobaugh, T.P., Jr.; Frye, J.G. Characterization of small ColE1-like plasmids conferring kanamycin resistance in Salmonella enterica subsp. enterica serovars Typhimurium and Newport. Plasmid 2010, 63, 150-154. [CrossRef]

13. Chen, C.Y.; Strobaugh, T.P., Jr.; Lindsey, R.L.; Frye, J.G.; Uhlich, G. Sequence analysis of a group of low molecular-weight plasmids carrying multiple IS903 elements flanking a kanamycin resistance aph gene in Salmonella enterica serovars. Plasmid 2011, 65, 246-252. [CrossRef] [PubMed]

14. Chen, C.-Y.; Strobaugh, T.P.; Nguyen, L.-H.T.; Abley, M.; Lindsey, R.L.; Jackson, C.R. Isolation and characterization of two novel groups of kanamycin-resistance ColE1-like plasmids in Salmonella enterica serotypes from food animals. PLoS ONE 2018, 13, e0193435. [CrossRef] [PubMed]

15. McMillan, E.A.; Gupta, S.K.; Williams, L.E.; Jové, T.; Hiott, L.M.; Woodley, T.A.; Barrett, J.B.; Jackson, C.R.; Wasilenko, J.L.; Simmons, M.; et al. Antimicrobial resistance genes, cassettes, and plasmids present in Salmonella enterica associated with United States food animals. Front. Microbiol. 2019, 10, 832. [CrossRef]

16. Tritt, A.; Eisen, J.A.; Facciotti, M.T.; Darling, A.E. An integrated pipeline for de novo assembly of microbial genomes. PLoS ONE 2012, 7, e42304. [CrossRef]

17. Carattoli, A.; Zankari, E.; Garcia- Fernandez, A.; Larsen, M.V.; Lund, O.; Villa, L.; Aarestrup, F.M.; Hasman, H. In silico detection and typing of plasmids using PlasmidFinder and plasmid multilocus sequence typing. Antimicrob. Agents Chemother. 2014, 58, 3895-3903. [CrossRef] [PubMed]

18. Overbeek, R.; Olson, R.; Pusch, G.D.; Olsen, G.J.; Davis, J.J.; Disz, T.; Edwards, R.A.; Gerdes, S.; Parrello, B.; Shukla, M.; et al. The SEED and the rapid annotation of microbial genomes using subsystems technology (RAST). Nucleic Acids Res. 2014, 42, D206-D214. [CrossRef]

19. Zankari, E.; Hasman, H.; Cosentino, S.; Vestergaard, M.; Rasmussen, S.; Lund, O.; Aarestrup, F.M.; Larsen, M.V. Identification of acquired antimicrobial resistance genes. J. Antimicrob. Chemother. 2012, 67, 2640-2644. [CrossRef] [PubMed]

20. Li, X.; Xie, Y.; Liu, M.; Tai, C.; Sun, J.; Deng, Z.; Ou, H.-Y. oriTfinder: A web-based tool for the identification of the origin of transfers in DNA sequences ofbacterial mobile genetic elements. Nucleic Acids Res. 2018, 46, W229-W234. [CrossRef] [PubMed]

21. Norman, A.; Hansen, L.H.; She, Q.; Sorensen, S.J. Nucleotide sequence of pOLA52: A conjugative IncX1 plasmid from Escherichia coli which enables biofilm formation and multidrug efflux. Plasmid 2008, 60, 59-74. [CrossRef]

22. Darling, A.E.; Mau, B.; Perna, N.T. progressiveMauve: Multiple genome alignment with gene gain, loss and rearrangement. PLoS ONE 2010, 5, e11147. [CrossRef]

23. Sampei, G.; Furuya, N.; Tachibana, K.; Saitou, Y.; Suzuki, T.; Mizobuchi, K.; Komano, T. Complete genome sequence of the incompatibility group I1 plasmid R64. Plasmid 2010, 64, 92-103. [CrossRef]

24. Alikhan, N.F.; Petty, N.K.; Ben Zakour, N.L.; Beatson, S.A. BLAST Ring Image Generator (BRIG): Simple prokaryote genome comparisons. BMC Genom. 2011, 12, 402. [CrossRef] [PubMed]

25. Moran, R.A.; Hall, R.M. Analysis of pCERC7, a small antibiotic resistance plasmid from a commensal ST131 Escherichia coli, defines a diverse group of plasmids that include various segments adjacent to a multimer resolution site and encode the same NikA relaxase accessory protein enabling mobilisation. Plasmid 2017, 89, 42-48. [CrossRef] [PubMed]

26. Torresen, O.K.; Star, B.; Mier, P.; Andrade-Navarro, M.A.; Bateman, A.; Jarnot, P.; Gruca, A.; Grynberg, M.; Kajava, A.V.; Promponas, V.J.; et al. Tandem repeats lead to sequence assembly errors and impose multi-level challenges for genome and protein databases. Nucleic Acids Res. 2019, 47, 10994-11006. [CrossRef] [PubMed] 